\title{
Analysis of Customers Purchase Patterns of E-Commerce Transactions Using Apriori Algorithm and Sales Forecasting Analysis With Weighted Moving Average (WMA) Method
}

\author{
Nanang Riyadi \\ Faculty of Information Technology \\ Budi Luhur University \\ Jakarta, Indonesia \\ nanangriyadi2@gmail.com \\ Muhammad Fariz Mulki \\ Faculty of Information Technology \\ Budi Luhur University \\ Jakarta, Indonesia \\ muhammadfarizmulki@gmail.com \\ Richard Susanto \\ Faculty of Information Technology \\ Budi Luhur University \\ Jakarta, Indonesia \\ richardsusantoubl@gmail.com
}

DOI: $10.31364 / S C I R J / v 7 . i 7.2019 . P 0719670$

http://dx.doi.org/10.31364/SCIRJ/v7.i7.2019.P0719670

\begin{abstract}
The challenge of today's e-commerce companies is how to extract large data into information for decision making, especially in terms of promoting products to be relevant, effective and efficient. At this time the XYZ company uses product category data as the main parameter in promoting its products to customers, but the method used is not optimal and efficient because promotions are not displayed to potential customers based on customer purchasing patterns. so that the sales target is not achieved, therefore market basket analysis is needed to find and understand the basic patterns of association rules that occur in customer purchase transactions. In this study the algorithm used is the Apriori algorithm, apriori algorithm is chosen because the resulting association rules have higher accuracy than the FP-Growth algorithm. Then the results of the apriori algorithm association rules are used as a reference in determining the items to be promoted, then sales forecasting is carried out with the Weighted Moving Average (WMA) method to predict the estimated total sales. The results of this study are apriori algorithm that has a higher accuracy value of $\mathbf{1 3 0 . 7 5}$ accompanied by sales forecasting analysis with a weighted moving average method that can be implemented in association rules generated from the Apriori algorithm so that it can help companies make decisions in the category of products that are sold a lot.
\end{abstract}

Index Terms-data mining, market basket analysis, Apriori, FP-growth sales Forecasting, weighted moving average

\section{INTRODUCTION}

At present, the XYZ company uses product category data as the main parameter in promoting its products to customers, but the method used is not running optimally and efficiently because promotions are not displayed to potential customers based on customer purchasing patterns. so that the sales target is not achieved, therefore market basket analysis is needed to find and understand the basic patterns of association rules that occur in customer transactions. Therefore, in this study, the algorithm that will be used is the Apriori algorithm and the frequent pattern growth (FP-Growth) algorithm. Both of these algorithms will be used as a reference for formulating association rules produced by the market basket analysis model using Rapidminer software version 9.0.

Association rules that will be generated by each of the Apriori algorithms and FP-Growth will be evaluated and analyzed to find algorithms that have higher accuracy. Algorithms with higher association rules will be used as a reference in determining the items to be promoted, then sales forecasting is done by the weighted moving average method to predict the estimated total sales. 
By doing this research, it is expected to provide results in the form of useful information and can be used to help related parties in making managerial decisions, especially those related to the formulation of marketing strategies.

\section{THEORETICAL BASIS}

\section{A. Literature Review}

\section{Data Mining}

Data mining is a process to find relationships, patterns, and trends by sorting through large amounts of data stored in storage media using pattern recognition technology and statistics and mathematics [1]. Data mining is often also called knowledge discovery in database (KDD), is an activity that includes the collection, use of historical data to find order, pattern or relationship in large data sets. The output of data mining can be used to improve future decision making [2].

Data mining is divided into several model groups based on tasks that can be done as follows [3]:

a. Prediction model (modeling prediction) This work is related to pembutan a model that can do the mapping of each set of variables to each target, then use the model to provide the target value in the new set obtained.

b. Cluster analysis Group analysis groups data into a number of groups based on the characteristics of each data in the groups.

c. Association analysis Association analysis is used to find patterns that illustrate the strength of the relationship of features in the data.

d. Detection of anomalies (anomaly detection) Anomalous detection work is related to observing a data from a number of data which significantly has different characteristics from the rest of the data.

\section{Market Basket Analysis}

Market Basket Analysis is an experiment to analyze consumer buying habits by finding relationships between different items, which are placed in a shopping basket (shopping basket) that are purchased when making certain transactions. The purpose of market basket analysis is to find out which products might be purchased simultaneously [4].

\section{Association Analysis}

Analysis of association or association rule is a data mining technique to find the rules of association between an item combination [5]. For example, customer purchasing patterns are very interesting to analyze. Valuable information can be generated from analyzing customer purchasing patterns so that they can be used to support business activities such as marketing promotions. One method that can be used to analyze customer purchasing patterns is association analysis. Analysis of associations with data mining techniques can find a relationship between a combination of items hidden in a database [6].
Apriori algorithm is one type of association rule in data mining. According to [7], apriori algorithm is a basic algorithm used for frequent itemset mining using association rules. This algorithm was first introduced by R. Agrawal and R. Srikant in 1994. Apriori algorithms use knowledge of past data as initial data. In its calculations, apriori algorithms use an iterative or iterative approach called level-wise search. The calculation starts by scanning the database and then accumulates the appearance of each item in each transaction then compares the accumulated results with the minimum support. The frequency itemset are obtained from itemset that meet the minimum support. Another important thing that must be known is the apriori property that reads: "all non-empty sets of a frequency item must be frequency".

\section{FP-Growth Algoritm}

FP-Growth Algorithm (Frequent Pattern-Growth) is one alternative to find a set of data that often appears (frequent itemset) without using generations of candidates (Wu and Kumar, 2009). In the selection of frequent items, do two processes that must be done, namely making FP-tree and the application of FPGrowth algorithm to find frequent itemset. The data structure used to search for items often with FP-Growth algorithm is complementary to the use of a tree prefix, commonly called FP-tree, FP-Growth algorithm can directly extract frequent itemset from FP-tree that has been created using the divide and conquer.

\section{Associaltion Rule Evaluation}

There are 2 factors that will be evaluated in this study, namely the measure of generality and the measure of reliability of the association rules produced. The measure of generality is used to find out how the level of occurrence of each item that is formulated in the association rules for the whole transaction. The formula used are:

\section{a. Support}

Support is a measure of how often collections of items in an association occur together as a percentage of all transactions. Here is the Formula:

$$
\text { Support }(A)=\frac{\text { total transactions contains } A}{\text { total transactions }}
$$

Size of reliability is used to determine the level of reliability of the association rules generated in association rules mining. The sizes used are:

b. Confidence

Confidence is a measure of uncertainty or trustworthiness related to each pattern found. Here is the Formula:

Confidence $=P(B \mid A)=\frac{\text { total transactions contains } A \text { dan } B}{\text { total transactions contains } A}$ 
Lift Ratio is a measure of how important rules have been formed in association rules based on the value of support and confidence. Lift calculations can be seen in the following equation. Here is the Formula:

$$
\text { Lift Rasio }=\frac{\text { confidence }}{\text { Benchmark confidence }}
$$

While the calculation of benchmark confidence can be seen in the equation

Benchmark Confidence $=\frac{\Sigma \text { transaction with item in consequet }}{\Sigma \text { transaction in database }}$

The value of lift ratio greater than 1 indicates the benefit of the rule. Higher lift ratio values, greater association strength [7].

7. Analysis of Association Evaluation Result

Analysis of the evaluation results was carried out on several association rules with the greatest confidence value generated by each algorithm, namely arpiori and FP-Growth. The level of strength of the association rules is determined by the value of support that represents aspects of generality and the value of confidence that represents the reliability aspects.

8. Forecasting

Forecasting is the calculated estimation values calculated from the modifiers or related changes. Fortune telling can also be based on expertise, which is basically based on historical data and experience [8]. Forecasting is past usage data from variables or a collection of variables to estimate its value in the future.

In this study, the forecasting method used is the weighted moving average model. The weighted moving average method uses the latest period data as historical data to make estimates, but each period gets different weights. Higher weight is usually given in periods that are getting closer to the forecast period (Eddy Herjanto, 2009). WMA calculations can be seen in the following equation:

$$
W M A=\frac{(\Sigma(D t * w e i g h t))}{(\Sigma w e i g h t)}
$$

Where:

$\mathrm{Dt}=$ actual data in period $\mathrm{t}$

weight $=$ weight given for each month

\section{Evaluation of Sales Forecasting Applications}

Evaluation of the application of sales forecasting can be known by calculating the difference between the original value and the forecasting value, commonly known as an error or error. The following is the method used to determine the magnitude of the error generated by a method of forecasting:

1. The Mean Absolute Deviation (MAD) Measures the accuracy of predictions by averaging estimated errors (absolute values of each error).
2. The Mean Squared Error (MSE) Is another method for evaluating forecasting methods. Each error or remainder is squared, then summed and divided by the number of observations.

3. The Mean Absolute Precentage Error (MAPE) Calculated by using absolute errors in each period divided by the real observation value for that period. Then it averages the absolute percentage error. This approach is useful when the size or size of the forecast variable is important in evaluating the accuracy of the forecast.

4. This method is very useful for calculating forecasting errors in the form of percentages rather than numbers. MAPE can be calculated using the formula:

\section{Software Quality Assurane}

Quality Assurance software is an activity used to guarantee that the software development process is done correctly. With the existence of SQA activities, it is expected that the needs and targets of the software developed can be achieved according to needs.

The importance of implementing SQA is basically to reduce costs and maintain the timeliness of the completion of software development. If software development suppresses the importance of software quality in all software development activities, basically this will reduce the amount of rework that must be done (Pressman, 2010).

\section{B. Study Review}

In his research [9] entitled "Implementation of Apriori Algorithms for Searching for Associations of Goods Sold on E-commerce OrderMas" Moh Sholik and Abu Salam [9] aims to Find Associations of Goods Sold on E-commerce OrderMas.

In his writing, the author takes the data that will be processed as an example, namely as many as 10 data on sales of goods as shown in the table below. The author gives a minimum value limit of support 0.5 or equal to $50 \%$. and confidence 0.5 or equal to $50 \%$.

\section{Study Review of Research Objects}

The research was conducted at XYZ company which is a joint venture between Telkom Indonesia and eBay. XYZ company has the concept of an Online Marketplace, the XYZ company has more than thousands of merchants offering millions of products from various categories that guarantee their originality and quality. XYZ successfully implemented various online marketing strategies such as clearance sale, strategic partnership and exclusive launch Pre-Order for various product categories including gadgets, computers and other electronic products.

The following are product promotion activities through ongoing digital advertising:

1. Promotion using a website based on the product categories.

2. Promotion using Google Ads. 
3. Promotion using Facebook Ads.

4. Promotion using Email Marketing.

\section{Conveptual Framework}

A mindset framework is created to visualize research problem solving concepts. The following is a mindset diagram diagram used in this study:

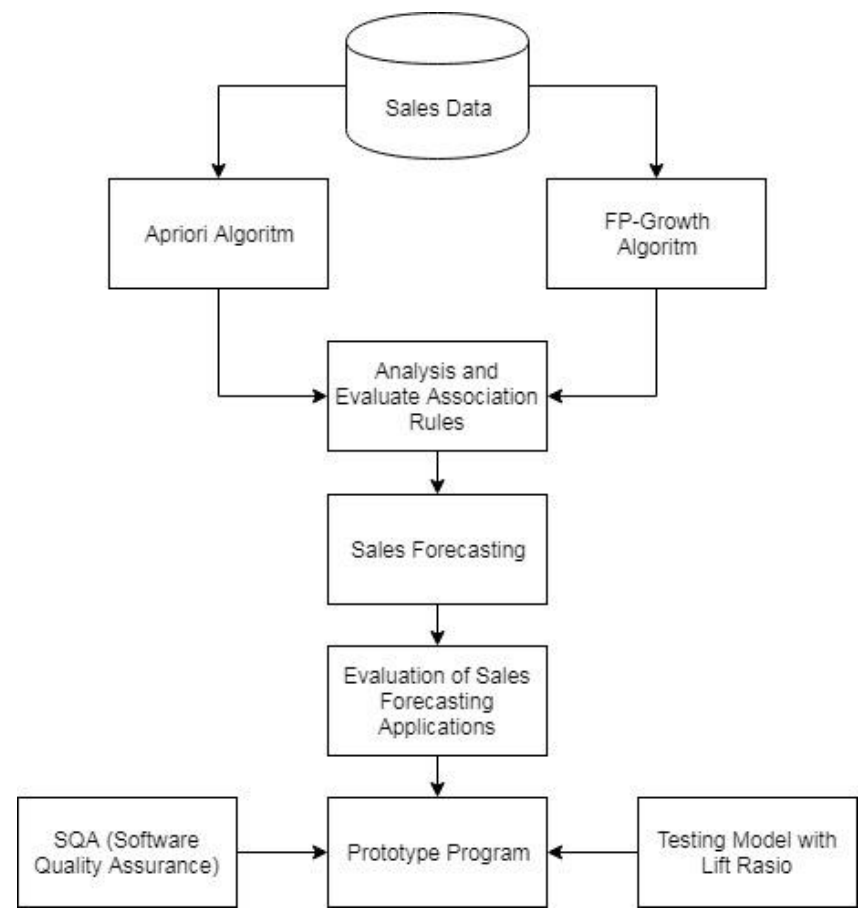

Figure 1. Conceptual Framework

\section{RESEARCH METHODOLOGY AND DESIGN}

\section{A. Research Methodology}

The research method used in this study used comparative experimental research. that is comparing two different objects, for example comparing two different algorithms by looking at the results of each statistic which is better research (Kothari, 2004). In this study, the type of research taken is comparative research by comparing two Apriori and FP-Growth algorithms.

The system development method used is the prototype method. The results of research using a prototype method are (initial estimation of the final system or product). The prototype will be built, approved, and then repeated as needed until the prototype is received by the XYZ company. It is expected that the results of this study can be directly used to solve problems related to product promotion activities.

\section{B. Sample Selection Methods}

In determining the sample, the sampling technique used was purposive sampling, which is a sampling technique based on specific criteria applied by the researcher. Provision of sample data is in one transaction. Need at least two items with valid purchase status and system recorded.

\section{Analysis Techniques}

This study is a descriptive study, descriptive analysis techniques carried out to analyze the data that will be used against the results of data analysis with literature studies, interviews and observations to obtain specifications of system requirements to be developed. In the analysis process several things will be carried out, namely as follows:

1. Analysis of the rules association method with the Apriori and FP-Growth algorithms.

2. Evaluate the results of the association rules from the Apriori and FP-Growth algorithms

3. Analysis of sales forecasting with the Weighted Moving Average method

4. Evaluate the results of sales forecasting with the Weighted Moving Average method

5. Problem analysis and functional and non-functional needs analysis

\section{Design Techniques}

The design technique used in this study is to use objectbased design using UML (Unified Modeling Language). In the design process the things done are as follows:

1. Designing a use case diagram.

2. Designing the user interface.

\section{E. Testing Techniques}

Testing is an investigation conducted to obtain information about the quality of the product or service being tested (under test). This study uses two testing methods, namely prototype quality testing using the SQA Quality Assurance Software method and testing the model using Lift Ratio. To ensure that the application prototype is made to have a minimum standard of quality, it is necessary to quantitatively measure the quality of software by using the Quality Assurance Software (SQA) method. Of the 22metrics found in SQA, 8 metrics are chosen that are suitable for business needs, as follows:

Table 1. SQA Quantitative

\begin{tabular}{|l|l|l|}
\hline Metric & Description & Weight \\
\hline Auditability & Meet the standard or not & 0.15 \\
\hline Accuracy & Computation computes & 0.15 \\
\hline
\end{tabular}

There are 8 (eight) criteria that can be used to measure the quality of a device by quantitative in Table 1 . The process of calculating SQA is as follows: Knowing the Number of Metrics that there are 8 no, then the added value is obtained from:

$$
\frac{1}{\text { total metrics }}=\frac{1}{8}=0.125
$$

The model testing technique used to measure how important the rule has been formed based on the value of support and confidence is to use Lift Ratio. Lift Ratio is a ratio number that shows how many possibilities to find an attribute that appears together with other attributes compared to all occurrences of attributes that are fulfilled. Lift shows the power of rule over random events from antecedent and consequent based on their respective 
support. The elevator calculation can be seen in the following equation:

$$
\text { Lift Rasio }=\frac{\text { confidence }}{\text { Benchmark confidence }}
$$

While the calculation of benchmark confidence can be seen in the following equation:

$$
\text { Benchmark Confidence }=\frac{\Sigma \text { transaction with item in conse }}{\Sigma \text { transaction in database }}
$$

The value of lift ratio greater than 1 indicates the benefit of the rule. Higher value of lift ratio, greater strength of association.

\section{RESEARCH RESULTS}

\section{A. Use Case Diagram}

Use case diagram is a diagram that is used to determine the functionality and features of software from an actor's perspective. In this diagram also explains the actor's interaction with the system. Use case diagram prototype using Apriori can be seen in figure 2 .

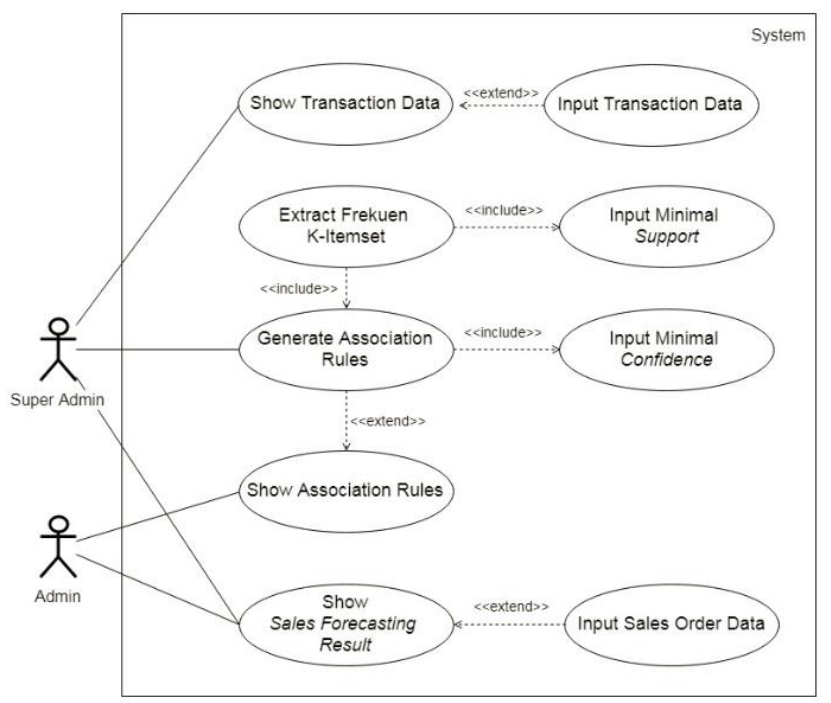

Figure 2. Use Case Diagram

Table 2 will explain in more detail the definition of actors associated with the system being built.

Figure 2. Actor Table

\begin{tabular}{|c|c|c|}
\hline No & Actor & Description \\
\hline 1 & $\begin{array}{c}\text { Super } \\
\text { Admin }\end{array}$ & $\begin{array}{c}\text { Actors who have the right to } \\
\text { full access to the system. }\end{array}$ \\
\hline 2 & Admin & $\begin{array}{c}\text { Actors who have been } \\
\text { registered in the system as } \\
\text { admin can only see the rules } \\
\text { generated and see the results } \\
\text { of sales forecasting. }\end{array}$ \\
\hline
\end{tabular}

Table 3 will explain in more detail about the use case used in figure 2 .

Table 3. Table User Case

\begin{tabular}{|c|l|l|}
\hline No & \multicolumn{1}{|c|}{ Use Case } & \multicolumn{1}{c|}{ Description } \\
\hline 1 & $\begin{array}{l}\text { See Product } \\
\text { Recommendations }\end{array}$ & $\begin{array}{l}\text { It is an activity to see } \\
\text { product recommendations } \\
\text { that are in the association } \\
\text { rules }\end{array}$ \\
\hline 2 & $\begin{array}{l}\text { View Data } \\
\text { Transaction }\end{array}$ & $\begin{array}{l}\text { It is activities to see a list } \\
\text { of sales transactions }\end{array}$ \\
\hline 3 & $\begin{array}{l}\text { View Data } \\
\text { Transaction }\end{array}$ & $\begin{array}{l}\text { It is activities to see a list } \\
\text { of sales transactions }\end{array}$ \\
\hline 4 & $\begin{array}{l}\text { Input Data } \\
\text { Transaction }\end{array}$ & $\begin{array}{l}\text { It is activities for entry } \\
\text { data transaction }\end{array}$ \\
\hline 5 & $\begin{array}{l}\text { See the Data } \\
\text { Mining Processing }\end{array}$ & $\begin{array}{l}\text { It is activities for entry } \\
\text { promotional data }\end{array}$ \\
\hline 6 & $\begin{array}{l}\text { Extract Frequent } \\
\text { K-Item Set }\end{array}$ & $\begin{array}{l}\text { It is activities to extract the } \\
\text { k-itemset frequency } \\
\text { iteration table }\end{array}$ \\
\hline 8 & $\begin{array}{l}\text { Input Minimal } \\
\text { Support }\end{array}$ & $\begin{array}{l}\text { It is activities for entry } \\
\text { minimum support values }\end{array}$ \\
\hline 7 & $\begin{array}{l}\text { Input Minimal } \\
\text { Confidence }\end{array}$ & $\begin{array}{l}\text { It is activities for entry } \\
\text { minimum confidence } \\
\text { values }\end{array}$ \\
\hline 8 & $\begin{array}{l}\text { Export Rules } \\
\text { Association }\end{array}$ & $\begin{array}{l}\text { It is activities to download } \\
\text { excel files as a result of } \\
\text { product associations from } \\
\text { Apriori calculations result. }\end{array}$ \\
\hline 9 & $\begin{array}{l}\text { Input Sales Data } \\
\text { It is activities to entry } \\
\text { sales data }\end{array}$ \\
\hline
\end{tabular}

B. Apriori Algoritm Flowchart 


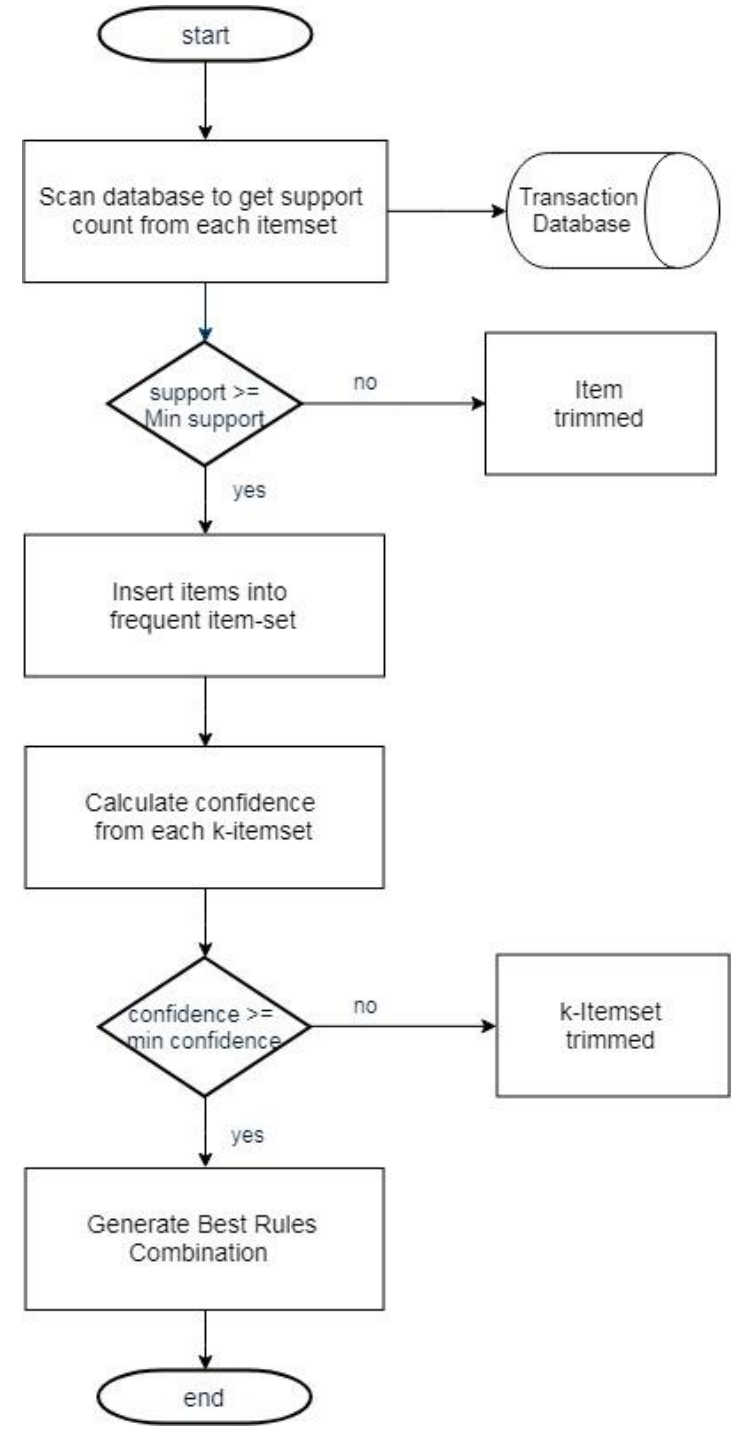

Figure 3. Apriori Algorithm Flowchart

\section{Data Processing}

In this section, explained the steps needed in data processing such as data selection, data pre-processing, selection of attributes, and making datasets.

\section{Data Selection}

The selection of data in this study is sales data at $\mathrm{XYZ}$ ecommerce company for 8 weeks in the period October 2018 - November 2018, the main data source used in this study is a dataset of company Sales Reports, along with the amount of data to be used:

Table 4. Total of Sales Data

\begin{tabular}{|c|c|c|}
\hline No & Table Name & Records \\
\hline 1 & Tbl_Transaction & 359 \\
\hline 2 & Tbl_ProductCategory & 29 \\
\hline 3 & Tbl_TransactionDetail & 764 \\
\hline
\end{tabular}

The data that will be used in processing data mining is transaction data that has an appearance with a minimum support of $2 \%$. The variable used in this study is the product category of sales transactions of 359 records, with valid sales data of 200 records that meet the criteria, namely transactions with a minimum of 2 product categories in one shopping basket. Of the total data, which is used as training data (training) of $151(75 \%)$ and test data (evaluation) as many as $49(25 \%)$.

\section{Pre-Data Processing}

To get quality data, there are several preprocessing or pre-processing techniques used, namely:

1. Data cleaning to eliminate noise, inconsistent data and incomplete data (missing value)

2. Data integration, which is combining data from several different tables, this process is done with the Join Sql command on the server.

3. Data selection is by taking relevant data from the database. Here is the sales data at $\mathrm{XYZ}$ ecommerce company for 8 weeks in the period October 2018 - November 2018 which only contains product categories.

4. Data transformation is done to combine data into forms that are appropriate for the data mining process.

\section{Selection of Attributes}

In this process data will be filtered and converted into tabular data by excel so that it becomes data that is ready to be processed in the data mining system process with apriori algorithm. From the data amounting to approximately 359 data records, after filtering the data that is ready to use, there are 200 data records with the attributes used, namely the product category.

4. Creating Dataset

Table 5. Data Training Structure

\begin{tabular}{|c|c|c|}
\hline Column Name & Data Type & Description \\
\hline Transaction_Id & Varchar & Transaction Number \\
\hline Transaction_date & Date & Transaction Date \\
\hline Product_Category & Varchar & Product Category \\
\hline
\end{tabular}

Tabel 6. Struktur Data Penjualan

\begin{tabular}{|c|c|c|}
\hline Column Name & Data Type & Description \\
\hline Product_Category & Varchar & Product Category \\
\hline Week_Index & Integer & Week items sold \\
\hline Month_Index & Integer & Month items sold \\
\hline Purchase & Integer & Total item sold \\
\hline
\end{tabular}

The data set above consists of two tables, transaction table and sales table, transaction table containing transaction data from October to November as many as 346 records, sales data contains product sales data based on product categories in october to november as many as 238 records to be used for sales forecasting.

\section{Discussion of Algormts}

In this section the algorithm will be used for comparison with its evaluation to produce the best association rules.

1. Apriori Algorimt

Apriori algorithm is a basic algorithm proposed by Agrawal \& Srikant in 1994 for determining frequent 
itemsets for Boolean association rules [7]. The process of data mining with apriori algorithm in this study will be conducted on training data that exceeds or equals the minimum (minimum support) of $2 \%$, then this data is applied to the Rapidminer application version 9.0. Transaction data used in training data is 151 transactions. The following is an example of a combination of item sets in training data.

Table 7. Examples of Apriori Algorithm Training Data Items

\begin{tabular}{|c|c|}
\hline Transaction ID & Item Set (Product Category) \\
\hline 418659822556073962 & $\begin{array}{l}\text { Indoor \& Outdoor Sports, } \\
\text { Mens Fashion }\end{array}$ \\
\hline 418642421421833550 & $\begin{array}{l}\text { Home Electronics, Video } \\
\text { Camera }\end{array}$ \\
\hline 418659826029007962 & $\begin{array}{l}\text { Bath \& Body, Hair Treatment, } \\
\text { Video Camera }\end{array}$ \\
\hline 418664505093423022 & $\begin{array}{l}\text { Beauty Equipments, Hair } \\
\text { Treatment }\end{array}$ \\
\hline 418659827195421962 & $\begin{array}{l}\text { Baby \& Kids Toys, Bath \& } \\
\text { Body }\end{array}$ \\
\hline 418659756008673962 & $\begin{array}{l}\text { Accessories, Baby \& Kids } \\
\text { Toys }\end{array}$ \\
\hline 418665220022323181 & $\begin{array}{l}\text { Bath \& Body, Beauty } \\
\text { Equipments }\end{array}$ \\
\hline 418659829195073962 & $\begin{array}{l}\text { Home Appliances, Laundry \& } \\
\text { Home Cleaning }\end{array}$ \\
\hline 418659831571973962 & $\begin{array}{l}\text { Indoor \& Outdoor Sports, } \\
\text { Mens Fashion }\end{array}$ \\
\hline 418690813362799030 & $\begin{array}{l}\text { Indoor \& Outdoor Sports, } \\
\text { Mens Clothing }\end{array}$ \\
\hline 418619350319771856 & $\begin{array}{l}\text { Beauty Equipments, Hair } \\
\text { Treatment }\end{array}$ \\
\hline 418604248047912715 & $\begin{array}{l}\text { Baby \& Kids Toys, Bath \& } \\
\text { Body }\end{array}$ \\
\hline 418642351164897751 & $\begin{array}{l}\text { Accessories \& Jewelry, Beauty } \\
\text { Equipments }\end{array}$ \\
\hline 418659824544307962 & Beauty Equipments, Bundling \\
\hline 418659834411807962 & Accessories \& Jewelry \\
\hline 418610720341768347 & $\begin{array}{l}\text { Accessories, Baby \& Kids } \\
\text { Toys }\end{array}$ \\
\hline 418641055389223064 & $\begin{array}{l}\text { Accessories, Accessories \& } \\
\text { Jewelry, Hair Treatment }\end{array}$ \\
\hline 418660115056123064 & $\begin{array}{l}\text { Accessories, Beverages, } \\
\text { Camera }\end{array}$ \\
\hline 418672747028723572 & $\begin{array}{l}\text { Foods, Skin Care, Womens } \\
\text { Fashion }\end{array}$ \\
\hline 418625512265827656 & $\begin{array}{l}\text { Computer \& Laptop } \\
\text { Accessories, Home } \\
\text { Electronics, Video Camera }\end{array}$ \\
\hline 418651201507382916 & $\begin{array}{l}\text { Bundling, Home Appliances, } \\
\text { Mens Fashion }\end{array}$ \\
\hline 418664209304677236 & $\begin{array}{l}\text { Bundling, Home Appliances, } \\
\text { Mens Fashion }\end{array}$ \\
\hline 418676023172577802 & $\begin{array}{l}\text { Medical Tools, Personal Care, } \\
\text { Sexual Health }\end{array}$ \\
\hline 418714520538977826 & $\begin{array}{l}\text { Medical Tools, Personal Care, } \\
\text { Sexual Health }\end{array}$ \\
\hline 418709653081677737 & $\begin{array}{l}\text { Accessories, Mens Fashion, } \\
\text { Womens Fashion }\end{array}$ \\
\hline 418663927523575340 & $\begin{array}{l}\text { Baby \& Kids Toys, Furnitures, } \\
\text { Indoor \& Outdoor Sports }\end{array}$ \\
\hline 418655214338088779 & $\begin{array}{l}\text { Home Appliances, Home } \\
\text { Decoration, Laundry \& Home }\end{array}$ \\
\hline
\end{tabular}

\begin{tabular}{|l|l|}
\hline & Cleaning \\
\hline 418666451444275340 & Bath \& Body, Foods \\
\hline 418672930245375340 & $\begin{array}{l}\text { Handphone, Mens Fashion, } \\
\text { Skin Care }\end{array}$ \\
\hline 418705824012713030 & $\begin{array}{l}\text { Bath \& Body, Make Up, } \\
\text { Personal Care }\end{array}$ \\
\hline 418594334587944173 & $\begin{array}{l}\text { Computer \& Laptop } \\
\text { Accessories, Home } \\
\text { Electronics, Mens Clothing }\end{array}$ \\
\hline 418707411128877519 & $\begin{array}{l}\text { Accessories, Electronic } \\
\text { Kitchen, Sexual Health }\end{array}$ \\
\hline 418656305241497751 & $\begin{array}{l}\text { Accessories, Electronic } \\
\text { Kitchen, Sexual Health }\end{array}$ \\
\hline 418705759457402030 & $\begin{array}{l}\text { Accessories \& Jewelry, } \\
\text { Beverages, Home Decoration }\end{array}$ \\
\hline 418709937217174602 & $\begin{array}{l}\text { Accessories \& Jewelry, } \\
\text { Beverages, Home Decoration }\end{array}$ \\
\hline 418709939507074602 & $\begin{array}{l}\text { Food Supplements, Medical } \\
\text { Tools, Sexual Health }\end{array}$ \\
\hline 418724054426490194 & $\begin{array}{l}\text { Food Supplements, Medical } \\
\text { Tools, Personal Care }\end{array}$ \\
\hline 418623552401737656 & Handphone, Skin Care \\
\hline 418690419211537737 & $\begin{array}{l}\text { Computer \& Laptop } \\
\text { Accessories, Handphone, } \\
\text { Mens Fashion }\end{array}$ \\
\hline 418689749182089204 & Bath \& Body, Make Up \\
\hline 418713829252489663 & Mens Clothing, Mens Fashion \\
\hline 418716747103489663 & Foods, Home Decoration \\
\hline 418710001125990194 & $\begin{array}{l}\text { Mens Clothing, Mens Fashion, } \\
\text { Womens Fashion }\end{array}$ \\
\hline 418640026561742667 & $\begin{array}{l}\text { Beauty Equipments, Hair } \\
\text { Treatment, Make Up }\end{array}$ \\
\hline 418680254075273340 & $\begin{array}{l}\text { Food Supplements, Womens } \\
\text { Fashion }\end{array}$ \\
\hline
\end{tabular}

The next step is to create table binaries in each combination of product set sales transaction item sets.

Table 8. Examples of Binary Table Data Training Apriori Algorithms

\begin{tabular}{|c|c|c|c|c|c|c|c|c|c|c|c|c|c|c|c|c|c|c|c|}
\hline Row Labels & Acc. & Acc. & Baby_- & Bat. & Be. & Ber- & Ben-. & ca. & ca & Bb. & fo. & Foo & Fur- & Hai. & Hon.- & Ha. & Ho. & Ho- & indo- \\
\hline 41895952525 & 0 & 0 & 0 & 0 & 0 & 0 & 0 & 0 & 0 & 0 & 0 & 0 & 0 & 0 & 0 & 0 & 0 & 0 & 1 \\
\hline 4186424214 & 0 & 0 & 0 & 0 & 0 & 0 & 0 & 0 & 。 & 。 & 。 & 。 & 。 & 0 & 。 & 0 & 。 & 1 & 。 \\
\hline 4808598280. & 0 & 0 & 0 & 1 & 0 & 0 & 0 & 0 & 0 & 0 & 0 & 0 & 0 & 1 & 0 & 0 & 0 & 0 & 0 \\
\hline C45050. & 0 & 0 & 0 & 0 & 1 & 0 & 0 & 0 & 。 & 。 & 0 & 。 & 0 & 1 & 。 & 0 & 。 & 0 & 0 \\
\hline 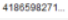 & 0 & 0 & 1 & , & 0 & 0 & 0 & 0 & 0 & 0 & 0 & 0 & 0 & 0 & 0 & 0 & 0 & 0 & 0 \\
\hline 4888597580. & 1 & 0 & 1 & 0 & 0 & 0 & 0 & 0 & 0 & 0 & 0 & 0 & 0 & 0 & 0 & 0 & 0 & 0 & 0 \\
\hline 4896852200 & 0 & 0 & 0 & 1 & 1 & 0 & 0 & 0 & 0 & 0 & 0 & 0 & 0 & 0 & 0 & 0 & 0 & 0 & 0 \\
\hline 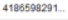 & 0 & 0 & 0 & 0 & 0 & 0 & 0 & 0 & 0 & 0 & 0 & 0 & 0 & 0 & 0 & 1 & 0 & 0 & 0 \\
\hline 406599315. & 0 & 0 & 0 & 0 & 0 & 0 & 0 & 0 & 0 & 0 & 0 & 0 & 0 & 0 & 0 & 0 & 0 & 0 & 1 \\
\hline 4 & 0 & 0 & 0 & 0 & 0 & 0 & 0 & 0 & 0 & 0 & 0 & 0 & 0 & 0 & 0 & 0 & 0 & 0 & 1 \\
\hline 4188995502. & 0 & 0 & 0 & 0 & 1 & 0 & 0 & 。 & 。 & 0 & 。 & 0 & 0 & 1 & 0 & 。 & 。 & 0 & 0 \\
\hline 4800042480 & 0 & 0 & 1 & ' & 0 & 0 & 0 & 0 & 0 & 0 & 0 & 0 & 0 & 0 & 0 & 0 & 0 & 0 & 0 \\
\hline 4186422511 & 0 & 1 & 0 & 0 & 1 & 0 & 。 & 。 & 0 & 0 & 。 & 0 & 0 & 0 & 0 & 。 & 。 & 0 & 0 \\
\hline 406590245. & 0 & 0 & 0 & 0 & 1 & 0 & 1 & 0 & 0 & 0 & 0 & 0 & 0 & 0 & 0 & 0 & 0 & 0 & 0 \\
\hline 4060590324 & 0 & 1 & 0 & 0 & 0 & 0 & 0 & 0 & 0 & 0 & 0 & 0 & 0 & 0 & 0 & 0 & 0 & 0 & 0 \\
\hline 50107203. & 1 & 0 & 1 & 0 & 0 & 0 & 0 & 0 & 0 & 0 & 0 & 0 & 0 & 0 & 0 & 0 & 0 & 0 & 0 \\
\hline
\end{tabular}

In table 8 above is a binary result at 7 where each transaction is seen as the appearance of each item.

Data mining with the association method in Rapidminer application version 9.0 can be done by entering binary data in table 8 above in formal xls. Then run the model as shown below: 


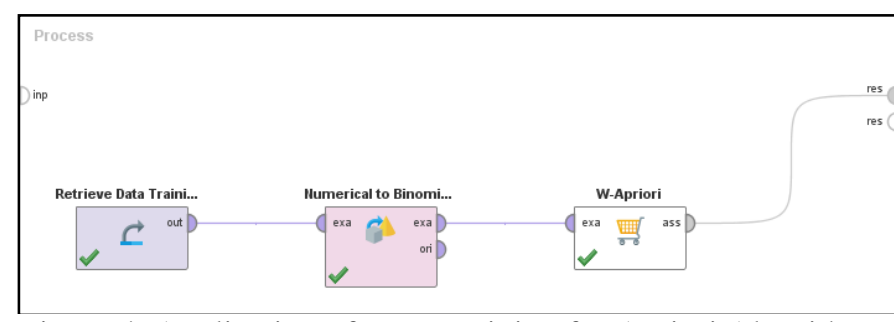

Figure 4. Application of Data Training for Apriori Algorithms on Rapidminer

The ten best association rules obtained from the application of market basket analysis with a Apriori algorithms are as follows:

Table 9. Rules of Association of Apriori Algorithms from Training Data

\begin{tabular}{|c|l|c|c|}
\hline No & \multicolumn{1}{|c|}{ Best Rules } & Supp & Conf \\
\hline 1 & $\begin{array}{l}\text { Beverages, Home Decoration ==> } \\
\text { Accessories \& Jewelry }\end{array}$ & 0.04 & 1 \\
\hline 2 & $\begin{array}{l}\text { Accessories \& Jewelry, Beverages ==> } \\
\text { Home Decoration }\end{array}$ & 0.04 & 1 \\
\hline 3 & Electronic Kitchen ==> Accessories & 0.03 & 1 \\
\hline 4 & Electronic Kitchen ==> Sexual Health & 0.03 & 1 \\
\hline 5 & $\begin{array}{l}\text { Electronic Kitchen, Sexual Health ==> } \\
\text { Accessories }\end{array}$ & 0.03 & 1 \\
\hline 6 & $\begin{array}{l}\text { Accessories, Electronic Kitchen ==> } \\
\text { Sexual Health }\end{array}$ & 0.03 & 1 \\
\hline 7 & $\begin{array}{l}\text { Electronic Kitchen ==> Accessories, } \\
\text { Sexual Health }\end{array}$ & 0.03 & 1 \\
\hline 8 & $\begin{array}{l}\text { Home Appliances, Mens Fashion ==> } \\
\text { Bundling }\end{array}$ & 0.03 & 1 \\
\hline 9 & $\begin{array}{l}\text { Bundling, Mens Fashion ==> Home } \\
\text { Appliances }\end{array}$ & 0.03 & 1 \\
\hline 10 & $\begin{array}{l}\text { Personal Care, Sexual Health ==> } \\
\text { Medical Tools }\end{array}$ & 0.03 & 1 \\
\hline
\end{tabular}

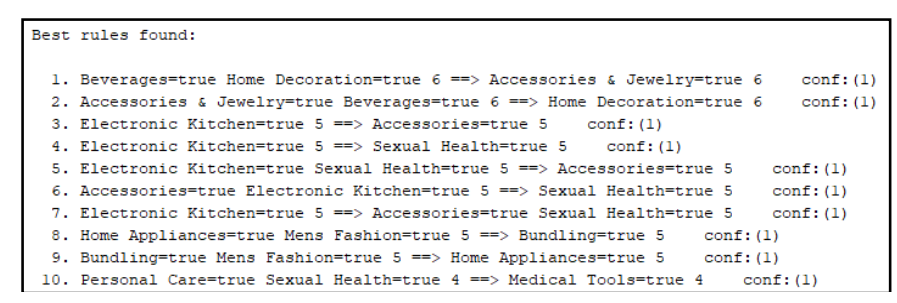

Figure 5. Ten Rules of the Best Data Training Association Apriori Algorithms in Rapidminer (Best Rules)

2. Evaluation of Apriori Algormts

Evaluate association rules on apriori algorithms by using elevator ratios to measure how important rules have been generated in association rules based on the value of support and confidence.

Table 10. Evaluation of the Rules of the Association of Apriori Algorithms from Training Data

\begin{tabular}{|c|c|c|c|c|}
\hline \multirow[b]{2}{*}{ No } & \multirow[b]{2}{*}{ Best Rules } & \multicolumn{3}{|c|}{ Apriori Algorithm } \\
\hline & & Supp & Conf & $\begin{array}{l}\text { Lift } \\
\text { Ratio }\end{array}$ \\
\hline 1 & $\begin{array}{l}\text { Beverages, Home Decoration } \\
==>\text { Accessories \& Jewelry }\end{array}$ & 0.04 & 1 & 10.07 \\
\hline 2 & $\begin{array}{l}\text { Accessories \& Jewelry, } \\
\text { Beverages }==>\text { Home } \\
\text { Decoration }\end{array}$ & 0.04 & 1 & 12.58 \\
\hline 3 & $\begin{array}{l}\text { Electronic Kitchen ==> } \\
\text { Accessories }\end{array}$ & 0.03 & 1 & 7.19 \\
\hline 4 & $\begin{array}{l}\text { Electronic Kitchen ==> Sexual } \\
\text { Health }\end{array}$ & 0.03 & 1 & 10.79 \\
\hline 5 & $\begin{array}{l}\text { Electronic Kitchen, Sexual } \\
\text { Health }==>\text { Accessories }\end{array}$ & 0.03 & 1 & 7.19 \\
\hline 6 & $\begin{array}{l}\text { Accessories, Electronic Kitchen } \\
==>\text { Sexual Health }\end{array}$ & 0.03 & 1 & 10.79 \\
\hline 7 & $\begin{array}{l}\text { Electronic Kitchen ==> } \\
\text { Accessories, Sexual Health }\end{array}$ & 0.03 & 1 & 30.20 \\
\hline 8 & $\begin{array}{l}\text { Home Appliances, Mens } \\
\text { Fashion ==> Bundling }\end{array}$ & 0.03 & 1 & 16.78 \\
\hline 9 & $\begin{array}{l}\text { Bundling, Mens Fashion ==> } \\
\text { Home Appliances }\end{array}$ & 0.03 & 1 & 12.58 \\
\hline 10 & $\begin{array}{l}\text { Personal Care, Sexual Health } \\
==>\text { Medical Tools }\end{array}$ & 0.03 & 1 & 12.58 \\
\hline \multicolumn{4}{|c|}{ Accuracy of Apriori Algorithm } & 130.75 \\
\hline
\end{tabular}

3. FP-Growth Algoritm

In determining the frequent itemset on the FPGrowth algorithm, there are two stages of the process that must be done, namely the making of FP-Tree and the application of the FP-Growth algorithm to find frequent itemset. The data structure used to search frequent itemset with FP-Growth algorithm is an extension of the use of a prefix tree, commonly called FP-Tree, FP-Growth algorithm can directly extract frequent itemset from formed FP-Tree.

In the construction of FP-Tree, twice the scanning database is required. scanning is first used to calculate the value of Support for each item and select products that meet the minimum support value and then sort them based on the number of frequencies or the biggest occurrence. The process of data mining with FP-Growth algorithm to find association rules is done on the same data as in the apriori algorithm, which is by using data in the T_training table.

Table 11. Ordering of Transaction Data Based on Support Value Count

\begin{tabular}{|l|l|r|}
\hline No & Itemset & $\begin{array}{l}\text { Support } \\
\text { Count }\end{array}$ \\
\hline 1 & Accessories & 21 \\
\hline 2 & Accessories \& Jewelry & 15 \\
\hline 3 & Baby \& Kids Toys & 15 \\
\hline 4 & Bath \& Body & 22 \\
\hline 5 & Beauty Equipments & 17 \\
\hline 6 & Beverages & 12 \\
\hline 7 & Bundling & 5 \\
\hline 8 & Camera & \\
\hline
\end{tabular}




\begin{tabular}{|l|l|r|}
\hline 9 & Computer \& Laptop Accessories & 12 \\
\hline 10 & Electronic Kitchen & 5 \\
\hline 11 & Food Supplements & 11 \\
\hline 12 & Foods & 9 \\
\hline 13 & Furnitures & 6 \\
\hline 14 & Hair Treatment & 16 \\
\hline 15 & Handphone & 9 \\
\hline 16 & Home Appliances & 12 \\
\hline 17 & Home Decoration & 12 \\
\hline 18 & Home Electronics & 10 \\
\hline 19 & Indoor \& Outdoor Sports & 11 \\
\hline 20 & Laundry \& Home Cleaning & 7 \\
\hline 21 & Make Up & 9 \\
\hline 22 & Medical Tools & 12 \\
\hline 23 & Mens Clothing & 15 \\
\hline 24 & Mens Fashion & 23 \\
\hline$\ldots$ & & 12 \\
\hline 29 & Womens Fashion & \\
\hline
\end{tabular}

Based on table 11 above, obtained itemset that have a frequency above the minimum support of $2 \%$, and $90 \%$ confidence, hereinafter referred to as FP-list.

Table 12. FP-List FP-Growth Algorithms

\begin{tabular}{|l|l|r|}
\hline No & Itemset & $\begin{array}{l}\text { Support } \\
\text { Count }\end{array}$ \\
\hline 1 & Mens Fashion & 23 \\
\hline 2 & Bath \& Body & 22 \\
\hline 3 & Accessories & 21 \\
\hline 4 & Beauty Equipments & 17 \\
\hline 5 & Hair Treatment & 16 \\
\hline 6 & Accessories \& Jewelry & 15 \\
\hline 7 & Baby \& Kids Toys & 15 \\
\hline 8 & Mens Clothing & 15 \\
\hline 9 & Sexual Health & 14 \\
\hline 10 & Beverages & 12 \\
\hline 11 & Computer \& Laptop Accessories & 12 \\
\hline 12 & Home Appliances & 12 \\
\hline 13 & Home Decoration & 12 \\
\hline 14 & Medical Tools & 12 \\
\hline 15 & Womens Fashion & 12 \\
\hline 16 & Food Supplements & 11 \\
\hline 17 & Indoor \& Outdoor Sports & 11 \\
\hline 18 & Personal Care & 11 \\
\hline 19 & Video Camera & 11 \\
\hline 20 & Home Electronics & 10 \\
\hline 21 & Bundling & 9 \\
\hline 22 & Foods & \\
\hline & & \\
\hline
\end{tabular}

\begin{tabular}{|r|l|r|}
\hline 23 & Handphone & 9 \\
\hline 24 & Make Up & 9 \\
\hline$\ldots$ & $\ldots$ & $\ldots$ \\
\hline 29 & Electronic Kitchen & 5 \\
\hline
\end{tabular}

After creating an FP-list, sort the itemset for each transaction based on the highest frequency according to the FP-list. Example itemset as follows:

Table 13. Ordering Itemset at Every Highest Frequency Based Transaction

\begin{tabular}{|l|l|l|}
\hline No & Transaction ID (TID) & Item Set \\
\hline 1 & 418659822556073962 & $\begin{array}{l}\text { Indoor \& Outdoor } \\
\text { Sports, Mens Fashion }\end{array}$ \\
\hline 2 & 418709653081677737 & $\begin{array}{l}\text { Accessories, Mens } \\
\text { Fashion, Womens } \\
\text { Fashion }\end{array}$ \\
\hline 3 & 418690419211537737 & $\begin{array}{l}\text { Computer \& Laptop } \\
\text { Accessories, Handphone, } \\
\text { Mens Fashion }\end{array}$ \\
\hline 4 & 418614035239607166 & $\begin{array}{l}\text { Accessories, Mens } \\
\text { Fashion, Womens } \\
\text { Fashion }\end{array}$ \\
\hline 5 & 418611340099644085 & $\begin{array}{l}\text { Accessories \& Jewelry, } \\
\text { Beverages, Home } \\
\text { Decoration, Womens } \\
\text { Fashion }\end{array}$ \\
\hline 6 & 418621955447612830 & $\begin{array}{l}\text { Computer \& Laptop } \\
\text { Accessories, Handphone, } \\
\text { Mens Fashion }\end{array}$ \\
\hline 7 & 418613139554160349 & $\begin{array}{l}\text { Accessories, Mens } \\
\text { Fashion, Womens } \\
\text { Fashion }\end{array}$ \\
\hline 8 & 418613649346964931 & $\begin{array}{l}\text { Beauty Equipments, Hair } \\
\text { Treatment, Womens } \\
\text { Fashion }\end{array}$ \\
\hline 11 & 418609007425913094 & $\begin{array}{l}\text { Mens Clothing, Mens } \\
\text { Fashion }\end{array}$ \\
\hline 12 & 418645054359036396 & $\begin{array}{l}\text { Mens Clothing, Mens } \\
\text { Fashion, Womens } \\
\text { Fashion }\end{array}$ \\
\hline & 418713829252489663 Mens Clothing, Mens \\
Fashion \\
$\ldots$
\end{tabular}

After the itemset are arranged based on an FP-list, a dataset is traced which is reading each transaction beginning 
with Transaction ID (TID) 418659822556073962 to make FPTree. The following are examples of table binaries that will be used in processing training data for FP-Growth algorithms:

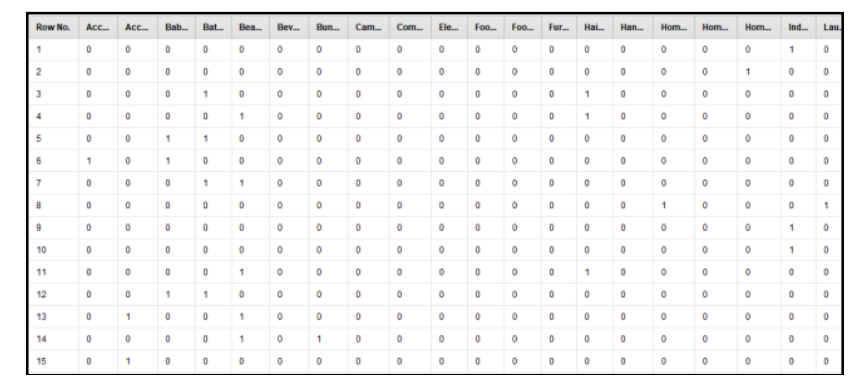

Figure 6. Example of Binary Data Training Table FP-Growth Algorithm

The next step is to apply the data to the rapidminer application with the Excel file format.

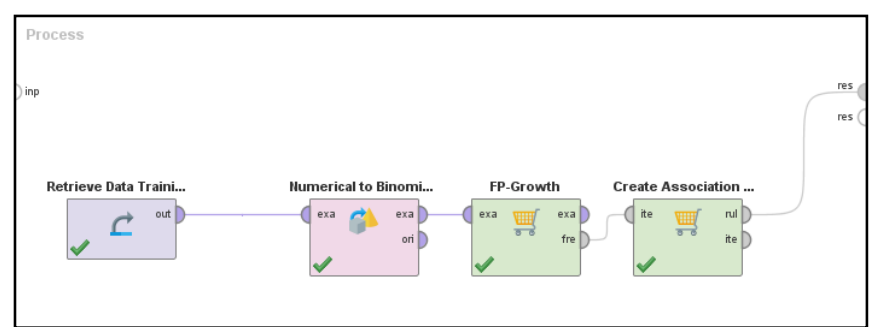

Figure 7. Application of FP-Growth Algorithm Training Data on Rapidminer

From the process of implementing the FP-Growth algorithm with the Rapidminer application above it produces ten of the best association rules as follows:

Table 14. Table of Rules for the Association of FP-Growth Algorithm Training Data

\begin{tabular}{|c|l|c|c|}
\hline No & \multicolumn{1}{|c|}{ Best Rules } & Supp & Conf \\
\hline 1 & $\begin{array}{l}\text { Electronic Kitchen ==> } \\
\text { Accessories }\end{array}$ & 0.03 & 1 \\
\hline 2 & $\begin{array}{l}\text { Electronic Kitchen ==> Sexual } \\
\text { Health }\end{array}$ & 0.03 & 1 \\
\hline 3 & $\begin{array}{l}\text { Mens Fashion, Accessories ==> } \\
\text { Womens Fashion }\end{array}$ & 0.02 & 1 \\
\hline 4 & $\begin{array}{l}\text { Accessories, Womens Fashion } \\
\text { ==> Mens Fashion }\end{array}$ & 0.02 & 1 \\
\hline 5 & $\begin{array}{l}\text { Mens Fashion, Computer \& } \\
\text { Laptop Accessories ==> } \\
\text { Handphone }\end{array}$ & 0.01 & 1 \\
\hline 6 & $\begin{array}{l}\text { Mens Fashion, Home Appliances } \\
\text { ==> Bundling }\end{array}$ & 0.03 & 1 \\
\hline 7 & $\begin{array}{l}\text { Mens Fashion, Bundling ==> } \\
\text { Home Appliances }\end{array}$ & 0.03 & 1 \\
\hline 8 & $\begin{array}{l}\text { Mens Fashion, Skin Care ==> } \\
\text { Handphone }\end{array}$ & 0.02 & 1 \\
\hline 9 & $\begin{array}{l}\text { Bath \& Body, Hair Treatment } \\
\text { ==> Video Camera }\end{array}$ & 0.02 & 1 \\
\hline 10 & $\begin{array}{l}\text { Hair Treatment, Video Camera } \\
\text { ==> Bath \& Body }\end{array}$ & 0.02 & 1 \\
\hline
\end{tabular}

4. Evaluation of FP-Growth Algoritm
Evaluation of association rules on FP-growth algorithm by using elevator ratio to measure how important the rule has been generated in association rules based on the value of support and confidence.

5. Pre-Data Processing

To get quality data, there are several preprocessing or pre-processing techniques used, namely

Table 15. Evaluation of Association Rules for FP Growth Data Training Algorithms

\begin{tabular}{|c|c|c|c|c|}
\hline \multirow{2}{*}{ No } & \multirow{2}{*}{ Best Rules } & \multicolumn{3}{|c|}{$\begin{array}{l}\text { FP-Growth } \\
\text { Algorithm }\end{array}$} \\
\hline & & Supp & Conf & $\begin{array}{c}\text { Lift } \\
\text { Ratio }\end{array}$ \\
\hline 1 & $\begin{array}{l}\text { Electronic Kitchen } \\
==>\text { Accessories }\end{array}$ & 0.03 & 1 & 7.19 \\
\hline 2 & $\begin{array}{l}\text { Electronic Kitchen } \\
==>\text { Sexual Health }\end{array}$ & 0.03 & 1 & 10.79 \\
\hline 3 & $\begin{array}{l}\text { Mens Fashion, } \\
\text { Accessories ==> } \\
\text { Womens Fashion }\end{array}$ & 0.02 & 1 & 12.58 \\
\hline 4 & $\begin{array}{l}\text { Accessories, Womens } \\
\text { Fashion ==> Mens } \\
\text { Fashion }\end{array}$ & 0.02 & 1 & 6.57 \\
\hline 5 & $\begin{array}{l}\text { Mens Fashion, } \\
\text { Computer \& Laptop } \\
\text { Accessories ==> } \\
\text { Handphone }\end{array}$ & 0.01 & 1 & 16.78 \\
\hline 6 & $\begin{array}{l}\text { Mens Fashion, Home } \\
\text { Appliances ==> } \\
\text { Bundling }\end{array}$ & 0.03 & 1 & 16.78 \\
\hline 7 & $\begin{array}{l}\text { Mens Fashion, } \\
\text { Bundling ==> Home } \\
\text { Appliances }\end{array}$ & 0.03 & 1 & 12.58 \\
\hline 8 & $\begin{array}{l}\text { Mens Fashion, Skin } \\
\text { Care ==> Handphone }\end{array}$ & 0.02 & 1 & 16.78 \\
\hline 9 & $\begin{array}{l}\text { Bath \& Body, Hair } \\
\text { Treatment ==> Video } \\
\text { Camera }\end{array}$ & 0.02 & 1 & 13.73 \\
\hline 10 & $\begin{array}{l}\text { Hair Treatment, Video } \\
\text { Camera ==> Bath \& } \\
\text { Body }\end{array}$ & 0.02 & 1 & 6.86 \\
\hline \multicolumn{4}{|c|}{ Accuracy of FP-Growth Algorithm } & 120.63 \\
\hline
\end{tabular}

6. Result of Evaluation of Apriori and FP-Growth Algoritm

Analysis of evaluation results is done by calculating the rule level of the association rules generated by each algorithm. The level of strength of the rules is determined by the value of support that represents aspects of generality and trust values that represent aspects of reliability. The following is a top-level assessment of the association rules produced:

a. Evaluation Result of Apriori Algoritm 
Table 16. Level of Accuracy of Association Rules Apriori Algorithm Against Training Data

\begin{tabular}{|c|c|c|c|c|c|}
\hline A & & B & Supp & Conf & $\begin{array}{c}\text { Supp } x \\
\text { Conf }\end{array}$ \\
\hline $\begin{array}{c}\text { Beverages, } \\
\text { Home } \\
\text { Decoration }\end{array}$ & $\Rightarrow$ & $\begin{array}{c}\text { Accessories } \\
\& \text { Jewelry }\end{array}$ & 0.04 & 1 & 0.040 \\
\hline $\begin{array}{c}\text { Accessories } \\
\& \text { Jewelry, } \\
\text { Beverages }\end{array}$ & $\Rightarrow$ & $\begin{array}{c}\text { Home } \\
\text { Decoration }\end{array}$ & 0.04 & 1 & 0.041 \\
\hline $\begin{array}{c}\text { Electronic } \\
\text { Kitchen }\end{array}$ & $\Rightarrow$ & Accessories & 0.03 & 1 & 0.033 \\
\hline $\begin{array}{c}\text { Electronic } \\
\text { Kitchen }\end{array}$ & $\Rightarrow$ & $\begin{array}{c}\text { Sexual } \\
\text { Health }\end{array}$ & 0.03 & 1 & 0.033 \\
\hline $\begin{array}{c}\text { Electronic } \\
\text { Kitchen, } \\
\text { Sexual } \\
\text { Health }\end{array}$ & $\Rightarrow$ & Accessories & 0.03 & 1 & 0.033 \\
\hline $\begin{array}{c}\text { Accessories, } \\
\text { Electronic } \\
\text { Kitchen }\end{array}$ & $\Rightarrow$ & $\begin{array}{c}\text { Sexual } \\
\text { Health }\end{array}$ & 0.03 & 1 & 0.033 \\
\hline $\begin{array}{c}\text { Electronic } \\
\text { Kitchen }\end{array}$ & $\Rightarrow$ & $\begin{array}{c}\text { Accessories } \\
\text { Sexual } \\
\text { Health }\end{array}$ & 0.03 & 1 & 0.033 \\
\hline $\begin{array}{c}\text { Home } \\
\text { Appliances, } \\
\text { Mens } \\
\text { Fashion }\end{array}$ & $\Rightarrow$ & Bundling & 0.03 & 1 & 0.033 \\
\hline $\begin{array}{c}\text { Bundling, } \\
\text { Mens } \\
\text { Fashion }\end{array}$ & $\Rightarrow>$ & $\begin{array}{c}\text { Home } \\
\text { Appliances }\end{array}$ & 0.03 & 1 & 0.033 \\
\hline $\begin{array}{c}\text { Personal } \\
\text { Care, Sexual } \\
\text { Health }\end{array}$ & $\Rightarrow$ & Medical \\
Tools
\end{tabular}

b. Evaluation Result of FP-Growth Algoritm

Table 17. Level of Accuracy of Association Rules FP-Growth Algorithm Against Training Data

\begin{tabular}{|c|l|c|c|c|c|}
\hline A & & B & Supp & Conf & $\begin{array}{c}\text { Supp x } \\
\text { Conf }\end{array}$ \\
\hline $\begin{array}{c}\text { Electronic } \\
\text { Kitchen }\end{array}$ & $\Rightarrow$ & $\begin{array}{c}\text { Accessor } \\
\text { ies }\end{array}$ & 0.03 & 1 & 0.03 \\
\hline $\begin{array}{c}\text { Electronic } \\
\text { Kitchen }\end{array}$ & $\Rightarrow$ & $\begin{array}{c}\text { Sexual } \\
\text { Health }\end{array}$ & 0.03 & 1 & 0.03 \\
\hline $\begin{array}{c}\text { Mens Fashion, } \\
\text { Accessories }\end{array}$ & $\Rightarrow>$ & $\begin{array}{c}\text { Womens } \\
\text { Fashion }\end{array}$ & 0.02 & 1 & 0.02 \\
\hline $\begin{array}{c}\text { Accessories, } \\
\text { Womens } \\
\text { Fashion }\end{array}$ & $\Rightarrow>$ & $\begin{array}{c}\text { Mens } \\
\text { Fashion }\end{array}$ & 0.02 & 1 & 0.02 \\
\hline $\begin{array}{c}\text { Mens Fashion, } \\
\text { Computer \& } \\
\text { Laptop } \\
\text { Accessories }\end{array}$ & $\Rightarrow$ & $\begin{array}{c}\text { Handpho } \\
\text { ne }\end{array}$ & 0.01 & 1 & 0.01 \\
\hline $\begin{array}{c}\text { Mens Fashion, } \\
\text { Home } \\
\text { Appliances }\end{array}$ & $\Rightarrow$ & $\begin{array}{c}\text { Bundling } \\
\text { Mens Fashion, } \\
\text { Bundling }\end{array}$ & $\Rightarrow>03$ & 1 & 0.03 \\
\hline Mens Fashion, & $\Rightarrow>$ & Handpho & 0.03 & 1 & 0.03 \\
es & & 1 & 0.02 \\
\hline
\end{tabular}

\begin{tabular}{|c|l|c|l|l|l|}
\hline Skin Care & & ne & & & \\
\hline $\begin{array}{c}\text { Bath \& Body, } \\
\text { Hair Treatment }\end{array}$ & $\Rightarrow>$ & $\begin{array}{c}\text { Video } \\
\text { Camera }\end{array}$ & 0.02 & 1 & 0.02 \\
\hline $\begin{array}{c}\text { Hair Treatment, } \\
\text { Video Camera }\end{array}$ & $\Rightarrow>$ & $\begin{array}{c}\text { Bath \& } \\
\text { Body }\end{array}$ & 0.02 & 1 & 0.02 \\
\hline \multicolumn{2}{|c|}{ Level of Rules Accuracy } & 0.25 \\
\hline
\end{tabular}

Table 18. Results Comparison of Support and Confidence of Apriori Algorithms and FP-Growth in Training Data

\begin{tabular}{|c|c|c|c|c|c|c|c|}
\hline \multicolumn{4}{|c|}{ Algorithm Apriori } & \multicolumn{4}{c|}{ Algorithm FP-Growth } \\
\hline Supp & Conf & $\begin{array}{c}\text { Sup x } \\
\text { Conf }\end{array}$ & $\begin{array}{c}\text { Lift } \\
\text { Ratio }\end{array}$ & Supp & Conf & $\begin{array}{c}\text { Sup x } \\
\text { Conf }\end{array}$ & $\begin{array}{c}\text { Lift } \\
\text { Ratio }\end{array}$ \\
\hline 0.04 & 1 & 0.040 & 10.07 & 0.03 & 1 & 0.03 & 7.19 \\
\hline 0.04 & 1 & 0.041 & 12.58 & 0.03 & 1 & 0.03 & 10.79 \\
\hline 0.03 & 1 & 0.033 & 7.19 & 0.02 & 1 & 0.02 & 12.58 \\
\hline 0.03 & 1 & 0.033 & 10.79 & 0.02 & 1 & 0.02 & 6.57 \\
\hline 0.03 & 1 & 0.033 & 7.19 & 0.01 & 1 & 0.01 & 16.78 \\
\hline 0.03 & 1 & 0.033 & 10.79 & 0.03 & 1 & 0.03 & 16.78 \\
\hline 0.03 & 1 & 0.033 & 30.20 & 0.03 & 1 & 0.03 & 12.58 \\
\hline 0.03 & 1 & 0.033 & 16.78 & 0.02 & 1 & 0.02 & 16.78 \\
\hline 0.03 & 1 & 0.033 & 12.58 & 0.02 & 1 & 0.02 & 13.73 \\
\hline 0.03 & 1 & 0.026 & 12.58 & 0.02 & 1 & 0.02 & 6.86 \\
\hline $\begin{array}{c}\text { Accuracy of } \\
\text { Apriori }\end{array}$ & $\mathbf{0 . 3 4}$ & $\mathbf{1 3 0 . 7 5}$ & $\begin{array}{c}\text { Accuracy of } \\
\text { FP-Growth } \\
\text { Algorithm }\end{array}$ & & $\mathbf{0 . 2 5}$ & $\mathbf{1 2 0 . 6 3}$ \\
\hline
\end{tabular}

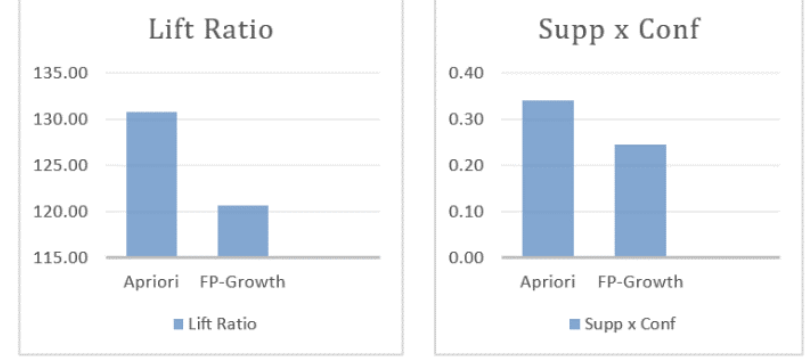

Figure 8. Comparison of Apriori and FP-Growth

The accuracy of the apriori algorithm and FP-growth association rules is measured by calculating the support multiplied by the confidence of each association rule produced. From table 18 it can be seen that the accuracy of the apriori algorithm is 0.34 while the accuracy of the FP-growth algorithm is 0.25 .

Based on the results of the evaluation of the two tested algorithms, it can be concluded that the association rules generated by the Apriori algorithm have better performance than the rules generated from the FP-Growth algorithm. Thus, the apriori algorithm will be implemented into a prototype analysis system for customer purchase patterns, and the resulting association rules will be used as a reference for the product to be promoted.

E. Sales Forecasting

1. Sales Forecasting with WMA 
Sales forecasting will use training data association rules that have higher accuracy, namely in the rules of apriori algortime association. In this study, the forecasting method used is time series with a weighted moving average model using 3 weights. Sales forecasting will be applied to sales data for the period October - November 2017, this is because to forecast sales data for one week ahead of the weighted moving average method requires actual sales data 3 weeks earlier.

The general form of the WMA (Weighted Moving Average) equation is:

WMA $=(\Sigma(\mathrm{Dt} *$ weight $)) /(\Sigma$ weight $)$

Where:

$\mathrm{Dt}=$ actual data in period $\mathrm{t}$

Weight $=$ weight given for each month

Table 19. Sales Forecasting with the first association rule (Beverages)

\begin{tabular}{|c|c|c|c|c|}
\hline & \multicolumn{4}{|c|}{ Beverages } \\
\hline & Period & $\begin{array}{l}\text { Sales } \\
\text { Figure }\end{array}$ & $\begin{array}{c}\text { Increase } \\
\text { Sales Figure }\end{array}$ & $\begin{array}{l}\text { WMA for } 3 \\
\text { Period }\end{array}$ \\
\hline \multirow[t]{4}{*}{ Oct } & W1 & 5 & 0 & \\
\hline & $\mathrm{W} 2$ & 8 & 3 & \\
\hline & W3 & 3 & -5 & \\
\hline & W4 & 11 & 8 & 5.0 \\
\hline \multirow[t]{4}{*}{ Nov } & W1 & 2 & -9 & 7.8 \\
\hline & W2 & 1 & -1 & 5.2 \\
\hline & W3 & 7 & 6 & 3.0 \\
\hline & W4 & 4 & -3 & 4.2 \\
\hline \multirow[t]{2}{*}{ Dec } & W1 & & & 4.5 \\
\hline & Avg & 5.125 & -0.125 & 4.9 \\
\hline
\end{tabular}

The table above explains the calculation of sales forecasting against the rules of the first association in the product Beverage category that is carried out in the period of data collection for a period of three months. The period column explains the number of weeks for two months while the sales figure column is the number of sales in that period.

The WMA column for 3 periods with 3 weights shows the results of the process that have been carried out by the method and within 2 months of data collection, because data is taken in 2 months or 8 weeks to estimate the following week, the October and November lines have no forecasting results while the forecasting results are in December.

\section{Evaluation of Sales Forecasting Application}

Evaluation of sales forecasting can be known by calculating the difference between the original value and the forecasting value, commonly known as error or error, here is an evaluation of the application of sales forecasting to product category data generated by training data association rules:

Table 20. Evaluation of Sales Forecasting Electronic Kitchen Product Categories

\begin{tabular}{|c|c|c|c|c|c|c|c|}
\hline & Period & $\begin{array}{l}\text { Sales } \\
\text { Figure }\end{array}$ & $\begin{array}{l}\text { WMA } \\
\text { for } 3 \\
\text { Period }\end{array}$ & Error & |Error| & Error2 & \%Error \\
\hline \multirow[t]{4}{*}{ Oct } & W1 & 1 & & & & & \\
\hline & W2 & 7 & & & & & \\
\hline & W3 & 8 & & & & & \\
\hline & W4 & 16 & 6.5 & 9.5 & 9.5 & 90.3 & 0.59 \\
\hline \multirow[t]{4}{*}{ Nov } & W1 & 3 & 11.8 & -8.8 & 8.8 & 78.0 & 2.94 \\
\hline & W2 & 4 & 8.2 & -4.2 & 4.2 & 17.4 & 1.04 \\
\hline & W3 & 12 & 5.7 & 6.3 & 6.3 & 40.1 & 0.53 \\
\hline & W4 & 9 & 7.8 & 1.2 & 1.2 & 1.4 & 0.13 \\
\hline \multirow[t]{3}{*}{ Dec } & W1 & & 9.2 & & & & \\
\hline & & & & & MAD & MSE & MAPE \\
\hline & & & & & 6.0 & 45.4 & $105 \%$ \\
\hline
\end{tabular}

In the table above, it can be seen the results of the sales forecasting calculation in the electronic kitchen product category with the moving average method obtaining the average Absolute Deviation (MAD) i.e. 6.0, Mean Square Error (MSE) which is 45.4 and Mean Absolute Percent Error (MAPE) is $105 \%$.

Tabel 21. Summary Evaluation for Sales Forecasting Application (Advanced)

\begin{tabular}{|c|c|c|c|c|c|}
\hline \multirow[b]{2}{*}{$\begin{array}{l}\mathrm{N} \\
\mathrm{o}\end{array}$} & \multirow[b]{2}{*}{ Association Rules } & \multicolumn{4}{|c|}{ Error } \\
\hline & & $\begin{array}{c}\text { Qty Sales } \\
\text { Forecastin } \\
\text { g } \\
\end{array}$ & $\begin{array}{l}\text { MA } \\
\text { D }\end{array}$ & MSE & $\begin{array}{c}\text { MAP } \\
\text { E }\end{array}$ \\
\hline \multirow{3}{*}{1} & Beverages & 4.5 & 4.0 & 20.7 & 1.6 \\
\hline & Home Decoration & 3.7 & 3.8 & 27.7 & 1.9 \\
\hline & $\begin{array}{l}\text { Accessories \& } \\
\text { Jewelry }\end{array}$ & 2.7 & 4.0 & 27.5 & 0.9 \\
\hline \multirow{3}{*}{2} & $\begin{array}{l}\text { Accessories \& } \\
\text { Jewelry }\end{array}$ & 2.7 & 4.0 & 27.5 & 0.9 \\
\hline & Beverages & 4.5 & 4.0 & 20.7 & 1.6 \\
\hline & Home Decoration & 3.7 & 3.8 & 27.7 & 1.9 \\
\hline \multirow{2}{*}{3} & Electronic Kitchen & 9.2 & 6.0 & 45.4 & 1.0 \\
\hline & Accessories & 55.5 & 16.2 & 328.5 & 0.3 \\
\hline \multirow{2}{*}{4} & Electronic Kitchen & 9.2 & 6.0 & 45.4 & 1.0 \\
\hline & Sexual Health & 5.0 & 9.7 & 193.3 & 4.9 \\
\hline \multirow{3}{*}{5} & Electronic Kitchen & 9.2 & 6.0 & 45.4 & 1.0 \\
\hline & Sexual Health & 5.0 & 9.7 & 193.3 & 4.9 \\
\hline & Accessories & 55.5 & 16.2 & 328.5 & 0.3 \\
\hline \multirow{3}{*}{6} & Accessories & 55.5 & 16.2 & 328.5 & 0.3 \\
\hline & Electronic Kitchen & 9.2 & 6.0 & 45.4 & 1.0 \\
\hline & Sexual Health & 5.0 & 9.7 & 193.3 & 4.9 \\
\hline
\end{tabular}




\begin{tabular}{|l|l|r|r|r|r|}
\hline \multirow{4}{*}{7} & Electronic Kitchen & 9.2 & 6.0 & 45.4 & 1.0 \\
\cline { 2 - 6 } & Accessories & 55.5 & 16.2 & 328.5 & 0.3 \\
\cline { 2 - 6 } & Sexual Health & 5.0 & 9.7 & 193.3 & 4.9 \\
\hline \multirow{4}{*}{8} & Home Appliances & 5.2 & 3.1 & 12.2 & 0.8 \\
\cline { 2 - 6 } & Mens Fashion & 130.8 & 43.0 & 8 & 0.6 \\
\cline { 2 - 6 } & Bundling & 63.8 & 23.9 & 846.9 & 1.0 \\
\hline \multirow{4}{*}{9} & Bundling & 63.8 & 23.9 & 846.9 & 1.0 \\
\cline { 2 - 6 } & Mens Fashion & 130.8 & 43.0 & 8 & 0.6 \\
\cline { 2 - 6 } & Home Appliances & 5.2 & 3.1 & 12.2 & 0.8 \\
\hline \multirow{3}{*}{10} & Personal Care & 7.2 & 3.9 & 33.7 & 1.4 \\
\cline { 2 - 6 } & Sexual Health & 5.0 & 9.7 & 193.3 & 4.9 \\
\cline { 2 - 6 } & Medical Tools & 9.2 & 3.2 & 16.0 & 0.8 \\
\hline
\end{tabular}

Based on data processing and analysis that has been done in the table above, sales forecasting with a weighted moving average model can be applied to association rules to be a reference for sales targets to be achieved based on the desired percentage increase in sales, with MAPE error rates (The Mean Absolute Percentage Error) below 2.0\%.

\section{Quality Assurance Software Testing (SQA)}

SQA Software Testing (Software Quality Assurance) is conducted to ensure that the prototype has a minimum standard of quality. This process is carried out by direct observation. The samples in this study are Product Owner, Analytics Specialist, IT Specialist, and SEM Specialist. The total number of respondents is 4 people. Of the 22-metrics found in SQA, 8 metrics were chosen that were in accordance with the needs of the company to assess the quality of the system prototypes that were built, as follows:

Table 22. Quality Assurance Software Testing Results

\begin{tabular}{|c|c|c|c|c|c|c|c|c|c|c|}
\hline \multirow{2}{*}{ No } & \multirow{2}{*}{ Respondents } & \multicolumn{10}{|c|}{ Metrics Score } & \multirow{2}{*}{ Score } \\
\cline { 3 - 11 } & & 1 & 2 & 3 & 4 & 5 & 6 & 7 & 8 & \\
\hline 1 & Product Owner & 80 & 80 & 80 & 60 & 80 & 100 & 80 & 80 & $\mathbf{8 0}$ \\
\hline 2 & Analytics Specialist & 80 & 100 & 80 & 60 & 80 & 80 & 80 & 80 & $\mathbf{8 2}$ \\
\hline 6 & IT Specialist & 80 & 60 & 60 & 100 & 100 & 80 & 80 & 60 & 76 \\
\hline 7 & SEM Specialist & 80 & 80 & 80 & 60 & 80 & 100 & 80 & 100 & $\mathbf{8 2}$ \\
\hline \multicolumn{11}{|c|}{ Average } \\
\hline \multicolumn{11}{|c|}{}
\end{tabular}

Based on the survey results in table 22 above, it can be concluded that the Customer Purchase Pattern Analysis Prototype meets the software quality standards set by the company, namely 70 , because the survey average value is above the minimum value of 80 .

\section{Model Testing}

Model testing with the Lift Ratio method is done to ensure that the model or algorithm used in the prototype can produce rules with good accuracy. So that the system prototype can produce association rules that can provide information accurately.
Table 23. Model Testing Results

\begin{tabular}{|c|c|c|c|c|c|c|}
\hline A & & B & Supp & Conf & $\begin{array}{c}\text { Supp } x \\
\text { Conf }\end{array}$ & $\begin{array}{c}\text { Lift } \\
\text { Ration }\end{array}$ \\
\hline $\begin{array}{l}\text { Beverages, } \\
\text { Home } \\
\text { Decoration }\end{array}$ & $\Rightarrow$ & $\begin{array}{c}\text { Accessories } \\
\text { \& Jewelry }\end{array}$ & 0.04 & 1 & 0.040 & 10.07 \\
\hline $\begin{array}{l}\text { Accessories } \\
\text { \& Jewelry, } \\
\text { Beverages }\end{array}$ & $\Rightarrow$ & $\begin{array}{c}\text { Home } \\
\text { Decoration }\end{array}$ & 0.04 & 1 & 0.041 & 12.58 \\
\hline $\begin{array}{l}\text { Electronic } \\
\text { Kitchen }\end{array}$ & $\Rightarrow$ & Accessories & 0.03 & 1 & 0.033 & 7.19 \\
\hline $\begin{array}{c}\text { Electronic } \\
\text { Kitchen }\end{array}$ & $\Rightarrow$ & $\begin{array}{l}\text { Sexual } \\
\text { Health }\end{array}$ & 0.03 & 1 & 0.033 & 10.79 \\
\hline $\begin{array}{c}\text { Electronic } \\
\text { Kitchen, } \\
\text { Sexual } \\
\text { Health } \\
\end{array}$ & $\Rightarrow$ & Accessories & 0.03 & 1 & 0.033 & 7.19 \\
\hline $\begin{array}{l}\text { Accessories, } \\
\text { Electronic } \\
\text { Kitchen }\end{array}$ & $\Rightarrow$ & $\begin{array}{l}\text { Sexual } \\
\text { Health }\end{array}$ & 0.03 & 1 & 0.033 & 10.79 \\
\hline $\begin{array}{l}\text { Electronic } \\
\text { Kitchen }\end{array}$ & $\Rightarrow$ & $\begin{array}{c}\text { Accessories, } \\
\text { Sexual } \\
\text { Health }\end{array}$ & 0.03 & 1 & 0.033 & 30.20 \\
\hline $\begin{array}{c}\text { Home } \\
\text { Appliances, } \\
\text { Mens } \\
\text { Fashion }\end{array}$ & $\Rightarrow$ & Bundling & 0.03 & 1 & 0.033 & 16.78 \\
\hline $\begin{array}{l}\text { Bundling, } \\
\text { Mens } \\
\text { Fashion }\end{array}$ & $\Rightarrow$ & $\begin{array}{c}\text { Home } \\
\text { Appliances }\end{array}$ & 0.03 & 1 & 0.033 & 12.58 \\
\hline $\begin{array}{c}\text { Personal } \\
\text { Care, } \\
\text { Sexual } \\
\text { Health }\end{array}$ & $\Rightarrow$ & $\begin{array}{l}\text { Medical } \\
\text { Tools }\end{array}$ & 0.03 & 1 & 0.026 & 12.58 \\
\hline \multicolumn{5}{|c|}{ Average } & 0.034 & 130.07 \\
\hline
\end{tabular}

Based on table 23 above the lift ratio for all rules generated by the Apriori algorithm has a value greater than 1 (lift ratio> 1). This shows that all these rules are strong and valid to be used as a reference in promotions and predict sales.

\section{Prototype Verification}

Based on the results of the prototype verification of the rapidminer application using $2 \%$ support and $90 \%$ confidence, it can be concluded that the accuracy produced by the prototype is $100 \%$ because the number of rules produced by the prototype is equal to the number of rapidminer rules that is 48 , with 29 rules having the same combination with rapidminer and 19 rules has a combination of similarities with rapidminer.

\section{CONCLUSIONS AND SUGGESTIONS}

\section{A. Conclusions}

From the results of this study entitled "Analysis of Customer Purchasing Patterns on E-Commerce Transactions Using Apriori Algorithms and Sales Forecasting Analysis with the Weighted Moving Average (WMA)" method, conclusions can be drawn as follows:

1) Based on the research that has been done, the Apriori algorithm is proven to produce better association rules based on the level of accuracy of the rules (lift ratio) strength that is equal to 130.75 compared to the FPGrowth Algorithm of 120.63.

2) The Apriori Algorithm can produce output in the form of recommendations for related product categories based on 
association rules that will be used as a reference for which product categories to promote.

3) The application of apriori algorithm in the form of a system prototype has met the standard value of the company's software quality assurance (SQA) testing of 80 , and verification of the prototype of the rapidminer application is $100 \%$ with a minimum support used of $2 \%$ and minimum confidence of $90 \%$.

4) Sales Forecasting with a weighted moving average (WMA) model using 3 weights can be implemented in the rules - the association of apriori algorithms to be used as a reference for sales targets that must be achieved based on the percentage increase in sales desired with MAPE error levels below $2.0 \%$.

\section{B. Suggestions}

Based on the description of the research discussion and conclusions obtained, it can be obtained for further research. As follows:

1) Apriori Algorithm with comparative algorithm for frequent growth patterns (FP-Growth). for further research other algorithms such as the K-Apriori algorithm or Vertical Format Algorithm can be applied as a comparison so that the algorithm can be accessed by those who have higher verification and can provide the appropriate research agreement.

2) To conduct sales forecasting, in this study using the weighted moving average model using 3 weights by taking data within 2 months behind, in future studies can use other methods that are more suitable to the needs.

\section{REFERENCES}

[1] Larose, D. T, "Discovering Knowledge in Data: An Introduction to Data Mining", John Willey \& Sons, Inc, 2005.

[2] Santosa, Budi, "Data Mining Teknik Pemanfaatan Data untuk Keperluan Bisnis", Graha Ilmu, Yogyakarta, 2007.

[3] Prasetyo, E. "Data Mining: Konsep Dan Aplikasi Menggunakan Matlab". Yogyakarta, Andi Publisher, 2012.

[4] Han, J. and Kamber, M. "Data Mining Concept and Tehniques. San Fransisco", Morgan Kauffman, 2006.

[5] Kusrini, "Algoritma Data Mining”, Jakarta, 2009

[6] Tan, P., Steinbach. M. \& Kumar. V. "Introduction to data Mining, Pearson Education", 2006

[7] Han, J. and Kamber, M. "Data Mining: Concepts and Data Mining: Concepts and Techniques: Chapter 6. Mining Association Rules in Large Databases", Simon Fraser University, 2000

[8] Box, G. E. P., Jenkins, G. M. and G.C.Reinsel, "Time Series Analysis: Forecasting and Control. New Jersey: Upper Saddle River", Prentice Hall, 1994

[9] Sholik, M. and Salam, A. "Implementasi Algoritme Apriori untuk Mencari Asosiasi Barang yang Dijual di E-commerce OrderMas'. Techno.COM. 17 (2): 158-170, 2018 